\title{
Results of Test Drilling in the Basalt Aquifer Near Fallon, Nevada
}

\section{Background}

Drilling of two test holes into the Fallon basalt aquifer commenced August 14, 2001. The basalt aquifer is located beneath the Carson Desert, near Fallon, Nevada, and is the sole source of drinking water for the City of Fallon, the Naval Air Station (NAS) Fallon, and the Fallon Paiute-Shoshone Tribe. Basalt comprising the aquifer is exposed at Rattlesnake Hill, an eroded volcanic cone, about 1 mile northeast of Fallon, and the remainder is buried beneath sediments deposited by the Carson River and ancient Lake Lahontan to depths of 600 feet near its edges (fig. 1). The basalt-aquifer system is a mushroom-shaped body of highly permeable volcanic rock. Viewed from above, the lateral extent of the basalt body is oval-shaped, about 4-miles wide and 10-miles long (fig. 1).

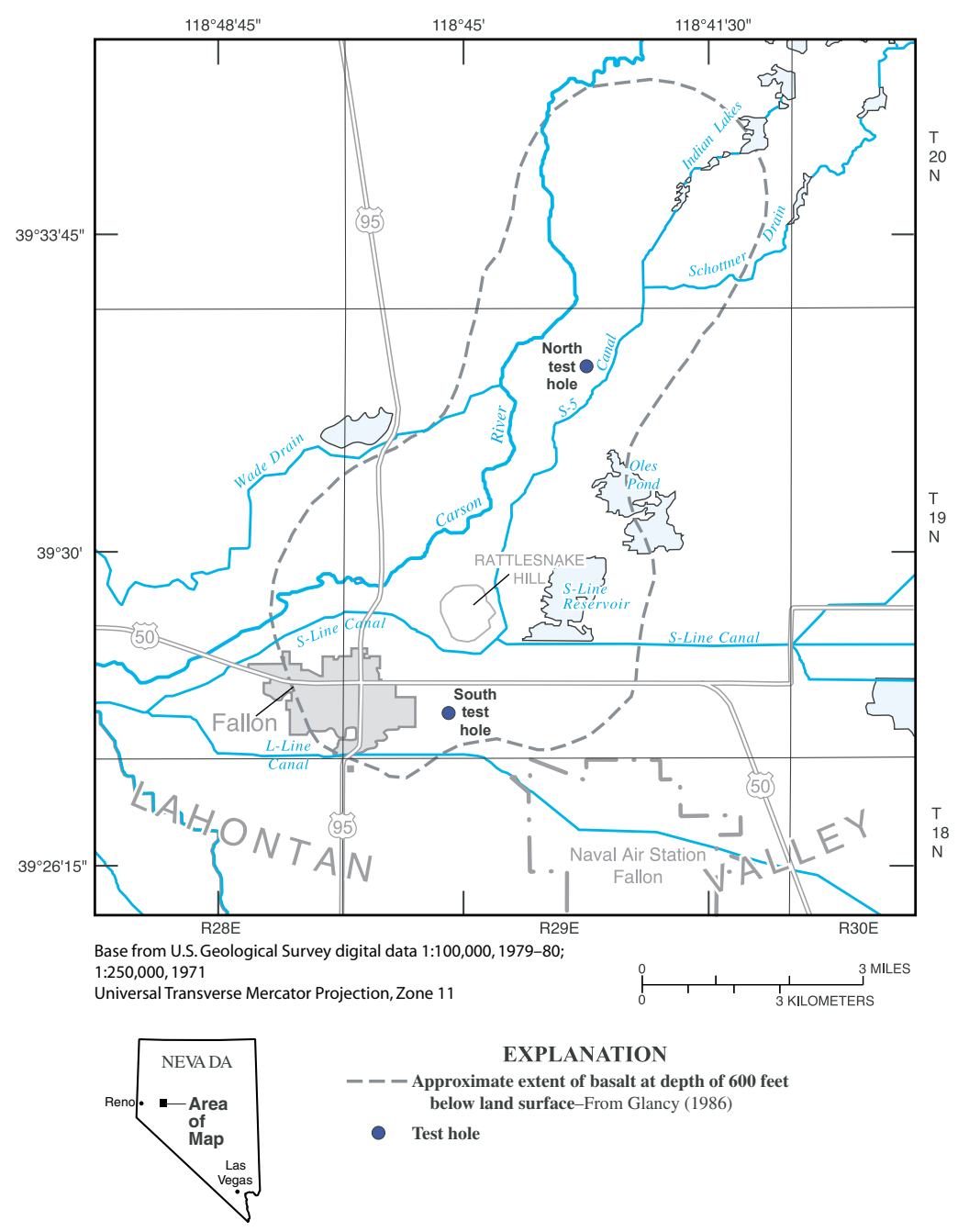

Figure 1. Approximate extent of basalt aquifer and location of test holes.
Drilling was part of a cooperative study between the U.S. Geological Survey (USGS), the Bureau of Reclamation, and NAS Fallon. The study was started because of concern about the continued viability of the basalt-aquifer system as a source of municipal water supply. Increased pumping from about 1,700 acre-feet per year (acre-ft/yr) in the 1970's to over 3,000 acre-ft/yr in the late 1990's has caused water levels in the basalt to decline as much as 12 feet (fig. 2). During this same time period, water pumped from the aquifer at NAS Fallon and the City of Fallon wells showed that concentrations of dissolved chloride increased, although chloride concentrations were well within the U.S. Environmental Protection Agency's (EPA) drinking-water standards; at this rate of increase, it would take decades to exceed the present standard (Maurer and Welch, 2001, p. 46). Concentrations of arsenic in the aquifer are about 0.1 milligrams per liter $(\mathrm{mg} / \mathrm{L})$, exceeding the drinking-water standard of $0.01 \mathrm{mg} / \mathrm{L}$, but show no apparent change over time (Maurer and Welch, 2001, p. 10 and 48; U. S. Environmental Protection Agency, 2001).

Increasing concentrations of chloride may be caused by increased pumping, that induces inflow of more saline water from aquifers surrounding or underlying the basalt, or from greater depths within the basalt itself. Prior to the drilling on August 14, 2001, few wells penetrated the basalt more than 70 feet below its upper surface (Maurer and Welch, 2001, p. 34). This prevented monitoring changes in water quality deeper in the aquifer that might be moving upward with continued pumping. Purposes of drilling were to fully penetrate the basalt, determine its hydrogeological character, the distribution of water quality in the basalt and in the underlying sedimentary aquifer, install monitoring wells.

\section{Drilling Results}

The first test hole is near the southern end of the basalt, about 1 mile south of Rattlesnake Hill, halfway between the Naval Air Station and City of Fallon wells (fig. 1). Basalt was encountered at a depth of 437 feet beneath alternating layers of sand and clay (figs. 3 and 4 ). The basalt there consists of very porous and fractured zones, alternating with more massive zones, to a depth of 730 feet below land surface throughout a total basalt thickness of 293 feet (figs. 3 and 4). As the test hole advanced through the basalt, specific conductance (an indicator of dissolved solids) was monitored to detect changes in water quality with depth. The measurements of specific conductance showed little change; however, when the bottom part of the basalt was penetrated, conductance abruptly increased 5-fold. 
Three 2-inch diameter monitoring wells were installed in the test hole, one each near the middle and bottom of the basalt, and one in the underlying sedimentary aquifer (fig. 4). Wells installed in the basalt produced water at rates of about 20 gallons per minute. Analyses of water pumped from the wells showed that the dissolved-solids concentration was 630 and $790 \mathrm{mg} / \mathrm{L}$ in the middle and bottom of the basalt, respectively, and was 3,800 $\mathrm{mg} / \mathrm{L}$ in sediments underlying the basalt (fig. 4). The drinkingwater standard for dissolved solids is $1,000 \mathrm{mg} / \mathrm{L}$ (U.S. Environmental Protection Agency, 2001). Dissolved arsenic concentrations in the middle and bottom of the basalt were 0.106 and $0.113 \mathrm{mg} / \mathrm{L}$, respectively, and $0.230 \mathrm{mg} / \mathrm{L}$ in sediments underlying the basalt, all exceeding drinking-water standards. Concentrations of dissolved chloride and iron in water from sediments underlying the basalt were 1,950 and $0.66 \mathrm{mg} / \mathrm{L}$, exceeding drinking-water standards of 400 and $0.60 \mathrm{mg} / \mathrm{L}$, respectively (U.S. Environmental Protection Agency, 2001). and $680 \mathrm{mg} / \mathrm{L}$ in sediments underlying the basalt (fig. 6). Concentrations of arsenic were 0.060 and $0.045 \mathrm{mg} / \mathrm{L}$ in the middle and bottom of the basalt, respectively, and $0.210 \mathrm{mg} / \mathrm{L}$ in sediments underlying the basalt, all exceeding drinking-water standards. Except for a dissolved chloride concentration of 840 $\mathrm{mg} / \mathrm{L}$ in the well installed near the bottom of the basalt, all other constituents analyzed were within drinking-water standards.

The test drilling at the two sites (figs. 7 and 8) showed that near the southern part of the aquifer, the area where most public supply wells are located, ground water from depths as great as 700 feet within the basalt aquifer were within the drinking-water standards except for dissolved arsenic. Ground water in sediments underlying the basalt near its southern extent greatly exceed drinking-water standards and could be a source for migration of poor-quality water into the basalt. The basalt aquifer near the location of the northern test hole does not
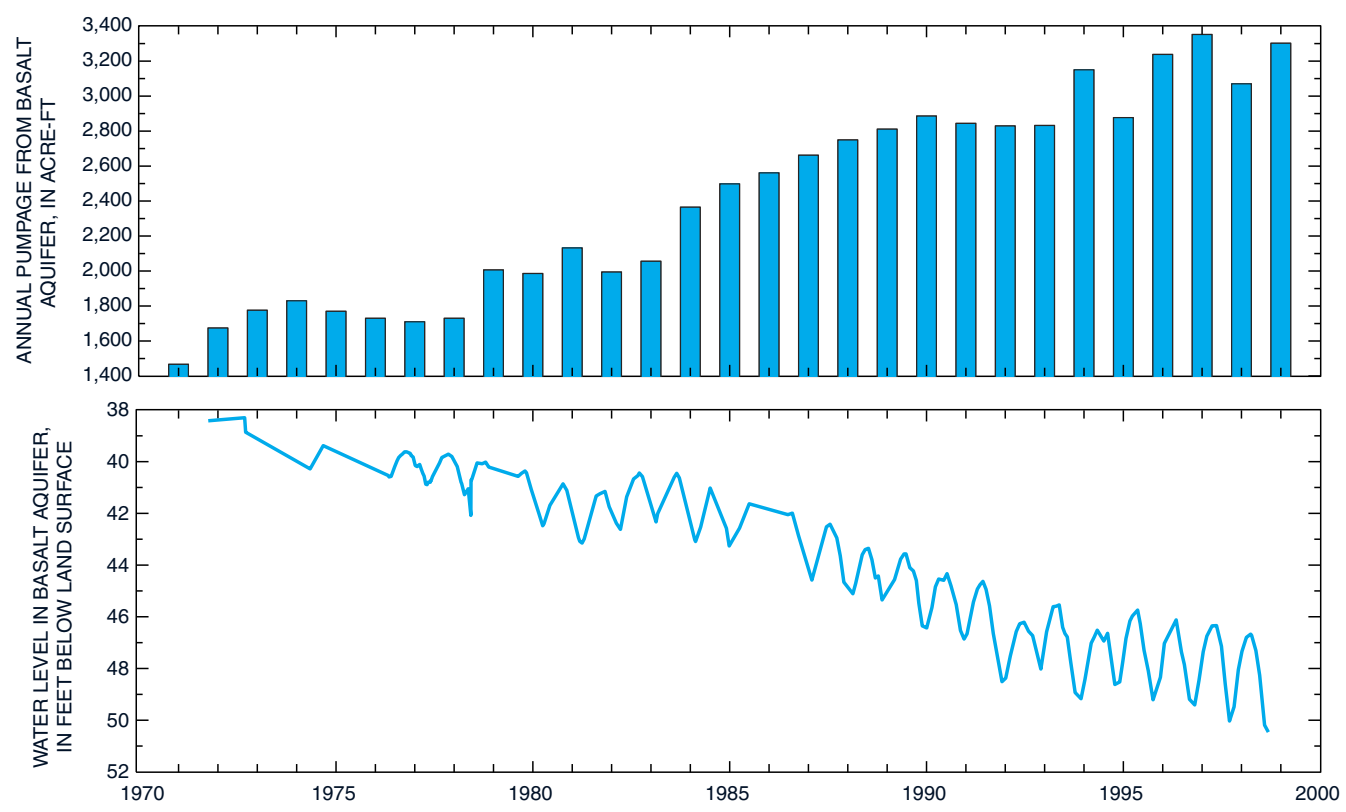

Figure 2. Annual pumpage from basalt aquifer and water-level changes in basalt aquifer.

Results of the water-quality analyses indicate the underlying sedimentary aquifer could be a source for migration of poorquality water into the basalt. Periodic sampling of the completed wells will provide a means to monitor changes in water quality as pumping from the basalt continues.

The northern test hole, drilled about 3 miles northeast of Rattlesnake Hill (fig. 1), encountered massive basalt breccia, basalt breccia with clay-filled fractures, and massive basalt from depths of 146 to 487 feet below land surface (figs. 5 and 6). Again, three 2-inch diameter monitoring wells were installed in the test hole, one each near the middle and bottom of the basalt, and one in the underlying sedimentary aquifer (fig. 6). Wells installed in the fractured breccia and underlying massive basalt produced water at rates of less than 1 and about 2 gallons per minute, respectively. Analyses of water pumped from the wells showed that the dissolved solids concentration was 810 and $2,100 \mathrm{mg} / \mathrm{L}$ in the middle and bottom of the basalt, respectively, readily yield large quantities of water to wells, and contains ground water with lower concentrations of dissolved arsenic than elsewhere in the aquifer. Water in sediments underlying the basalt at the northern test hole, although low in dissolved solids, has high concentrations of dissolved arsenic.

Additional test holes that would completely penetrate the basalt aquifer could be used to characterize the basalt and underlying sedimentary aquifers in terms of lithology, water quality, water levels, and hydraulic properties. This information would allow development of a numerical gound-water flow model of the basalt aquifer. The model would be used to refine estimates of the rates and sources of recharge to the basalt, and to determine long-term pumping rates that would maintain acceptable water levels and water quality in the aquifer.

Douglas K. Maurer 


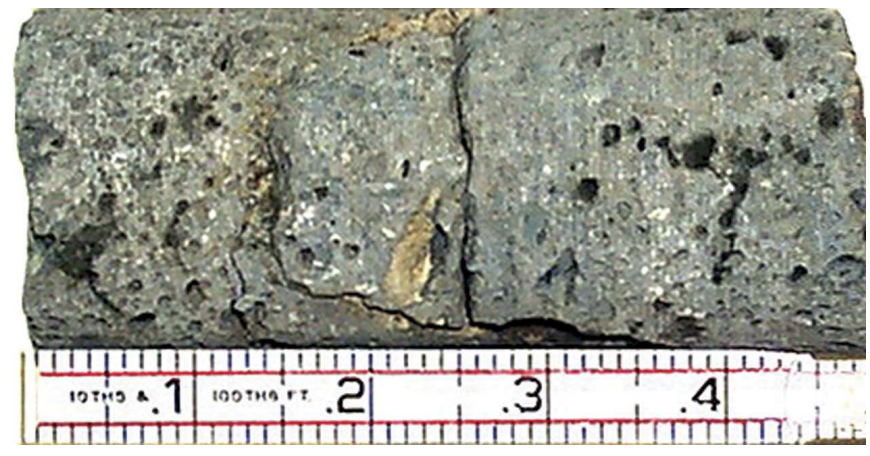

Figure 3. Core sample of the porous fractured basalt from the southern test hole.

Fallon Basalt - Southern test hole

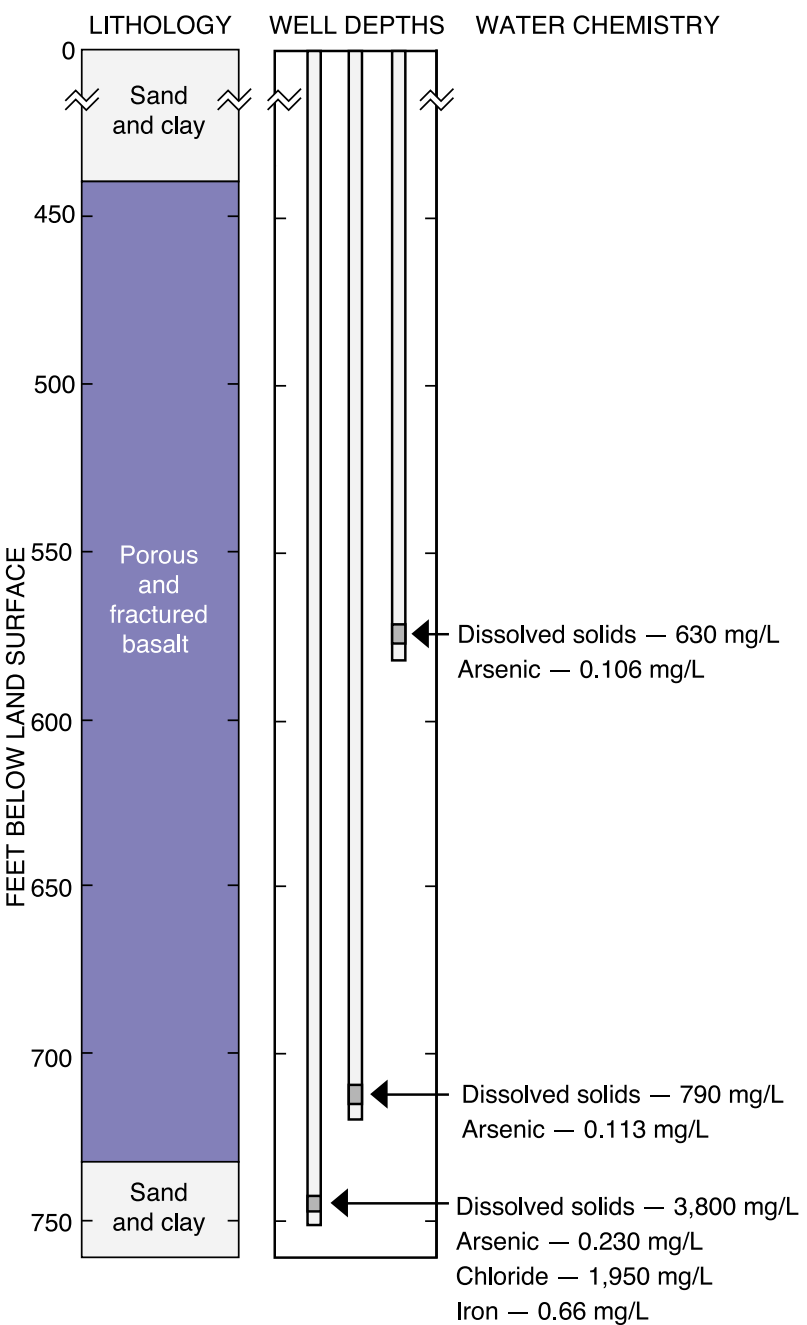

Figure 4. Lithology, well depths, and concentrations of selected constituents in southern test hole.

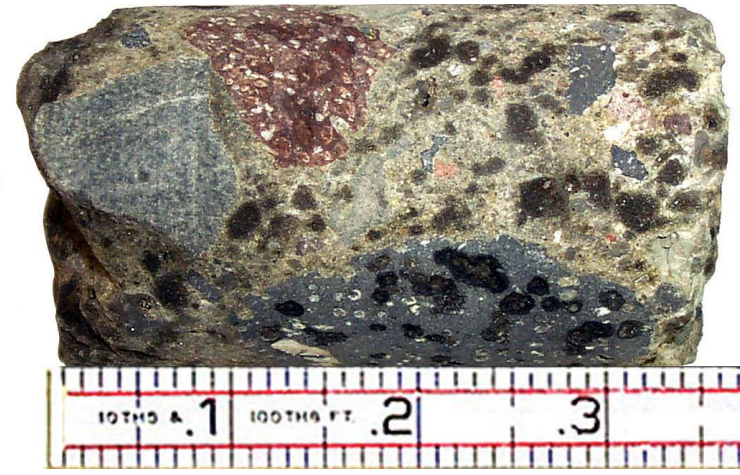

Figure 5. Core sample of the basalt breccia from the northern test hole.

\section{Fallon Basalt - Northern test hole}

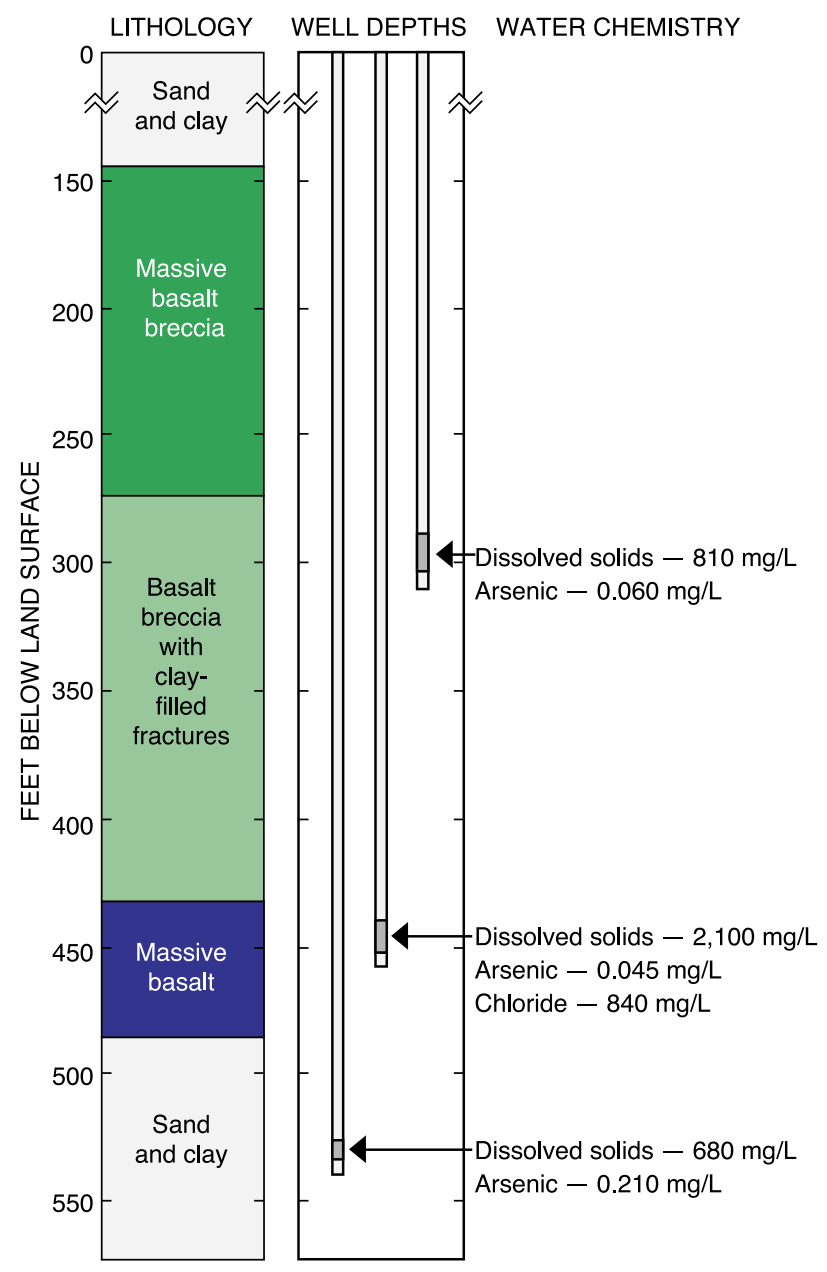

Figure 6. Lithology, well depths, and concentrations of selected constituents in northern test hole. 


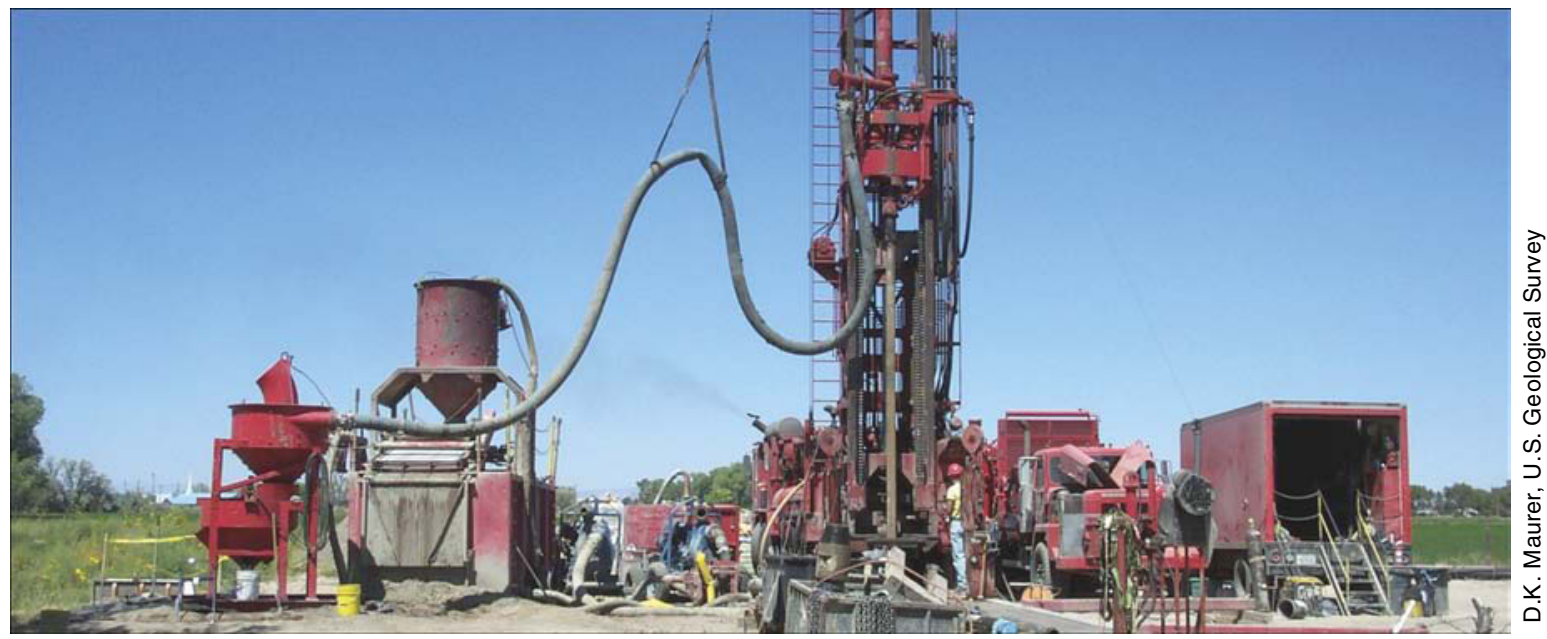

Figure 7. Drilling of the southern test hole in the Fallon basalt

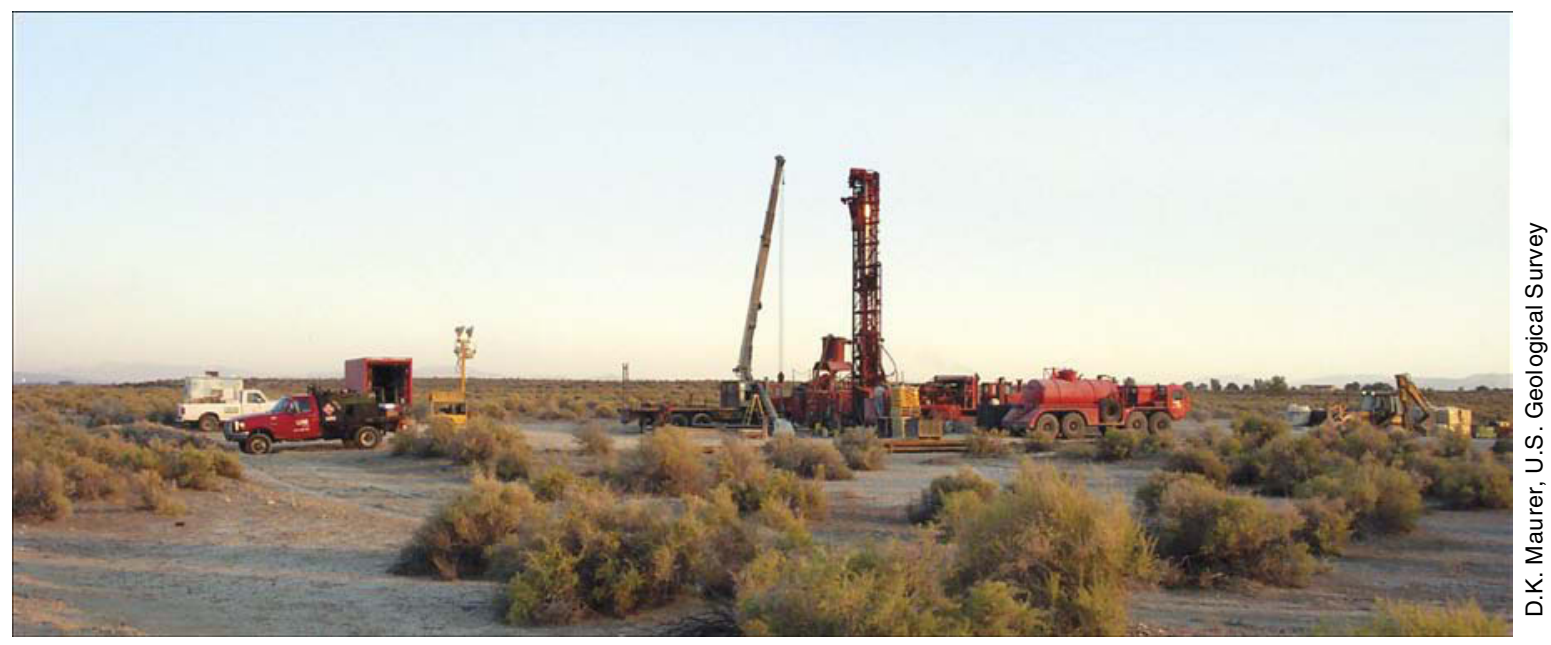

Figure 8. Drilling of the northern test hole in the Fallon basalt

\section{REFERENCES CITED}

Glancy, P.A., 1986, Geohydrology of the Basalt and Unconsolidated Sedimentary Aquifers in the Fallon Area, Churchill County, Nevada: U.S. Geological Survey WaterSupply Paper 2263, 62 p.

Maurer, D.K., and Welch, A.H., 2001, Hydrogeology and geochemistry of the Fallon basalt and adjacent aquifers, and potential sources of basalt recharge, in Churchill County, Nevada: U. S. Geological Survey Water-Resources Investigations Report 01-4130, 72 p.

U.S. Environmental Protection Agency, 2001, National Primary Drinking-Water Regulations: arsenic and clarifications to compliance and new source contaminants monitoring; final rule: Federal Register, U. S. Code of Federal Regulations, January 22, 2001, v. 66, no. 14, p. 6976-7066.
For more information on the U.S. Geological Survey studies described in this Fact Sheet, or on other aspects of water resources in Nevada, please contact: Public Information Assistant

U.S. Geological Survey

333 W. Nye Lane, Rm. 103

Carson City, Nevada

telephone: (775) 887-7649

fax: (775) 887-7629

email GS-W-NVpublic-info@usgs.gov

URL: http://nevada.usgs.gov 